Article

\title{
Effect of Fe Additives on the Catalytic Performance of Ion-Exchanged CsX Zeolites for Side-Chain Alkylation of Toluene with Methanol
}

\author{
Zhihui Zhang ${ }^{1,2}$, Xiaoling Yuan ${ }^{2}$, Songsong Miao ${ }^{2}$, Hui Li ${ }^{2}$, Wenlan Shan ${ }^{2}$, Mingjun Jia ${ }^{2, *(D)}$ \\ and Chunlei Zhang ${ }^{3, *}$ \\ 1 College of Chemical and Pharmaceutical Engineering, Jilin Institute of Chemical Technology, \\ Jilin 132022, China \\ 2 Key Laboratory of Surface and Interface Chemistry of Jilin Province, College of Chemistry, Jilin University, \\ Changchun 130012, China \\ 3 Education Ministry Key Lab of Resource Chemistry, Shanghai Key Laboratory of Rare Earth Functional Materials, \\ Shanghai Normal University, Shanghai 200234, China \\ * Correspondence: jiamj@jlu.edu.cn (M.J.); zhangchunlei@shnu.edu.cn (C.Z.); Tel.: +86-431-8515-5390 (M.J.); \\ Fax: +86-431-8516-8420 (M.J.)
}

Received: 13 September 2019; Accepted: 29 September 2019; Published: 1 October 2019

\begin{abstract}
The side-chain alkylation of toluene with methanol was investigated over some Fe-modified Cs ion-exchanged X zeolite (CsX) catalysts prepared via the impregnation method using different iron sources. The absorption/activation behaviors of the reactants on the surface of the catalysts were studied by in situ Fourier-transform infrared (FT-IR) spectroscopy and temperature programmed desorption (TPD) mass measurements. Modification of $\mathrm{CsX}$ with a small amount of $\mathrm{FeCl}_{3} \mathrm{Could}$ result in a considerable decrease in catalytic activity, due mainly to the remarkable decrease in the density of acidic and basic sites of the catalysts. Interestingly, the Fe( $\left.\mathrm{NO}_{3}\right)_{3}$-modified CsX with an optimum Fe loading of $0.15 \mathrm{wt}$ \% $\%$ shows improved catalytic activity and high yield compared to the side-chain alkylation products. Modification of $\mathrm{CsX}$ with $\mathrm{Fe}\left(\mathrm{NO}_{3}\right)_{3}$ could also result in a decrease in basic sites of the catalyst. However, such a change does not bring an obvious negative effect on the adsorption/activation of toluene, while it could effectively inhibit the generation of the undesired bidentate formate. Furthermore, the introduced $\mathrm{FeO}_{x}$ species (derived from the decomposition of $\left.\mathrm{Fe}\left(\mathrm{NO}_{3}\right)_{3}\right)$ may also act as new Lewis acidic sites to participate in the activation of methanol and to stabilize the formed active intermediates (i.e., unidentate formate). Therefore, modification of $\mathrm{CsX}$ with a suitable amount of $\mathrm{Fe}\left(\mathrm{NO}_{3}\right)_{3}$ may adjust its adsorption/activation ability for reagents by changing the acid-base properties of the catalyst, which can finally enhance the catalytic performance for the side-chain alkylation of toluene with methanol.
\end{abstract}

Keywords: toluene; methanol; side-chain alkylation; iron (Fe); CsX zeolite

\section{Introduction}

Styrene is an industrially essential chemical that is used for the synthesis of various polymers. Traditionally, styrene is synthesized via two subsequent catalytic reactions: the alkylation of benzene with ethylene to synthesize ethylbenzene, and the dehydrogenation of ethylbenzene to styrene. However, this method has some disadvantages, such as a high energy consumption, complicated operation process, and high cost of production. Therefore, recent studies focused on developing more simple and efficient ways to synthesize styrene. The side-chain alkylation of toluene with methanol is a very attractive reaction since it may offer an alternative method to produce styrene and ethylbenzene [1-5]. For this process, a variety of solid catalysts with different acid-base properties 
were investigated, including alkali metal ion-exchanged zeolites [6-10], alkaline porous $\mathrm{CaO}$ [11], Cs-containing microporous carbon [12], MgO encapsulated mesoporous zeolites [13], and layered double hydroxides (LDHs) [14]. As a representative catalyst system, Cs ion-exchanged X zeolites (CsX) received considerable attention for their relatively high catalytic activity and selectivity to styrene $[8,9,15]$. More interestingly, it was found that the catalytic performance of CsX may be further improved by modification with some additives $[9,16,17]$.

For instance, it was reported that modification of $\mathrm{CsX}$ with $\mathrm{Cs}_{2} \mathrm{O}$ could enhance the toluene conversion due to the generation of strong basic sites which promote the activation of toluene via the abstraction of a proton from the methyl group $[7,18]$. Hattori and coworkers reported that metal borate-modified CsX showed improved catalytic activity and selectivity compared to styrene owning to the ability of borates to selectively form formaldehyde from methanol [7,9]. Han et al. [17] gave a similar speculation after studying the side-chain alkylation reaction over composite catalysts composed of $\mathrm{CsX}$ and sodium borate $\left(\mathrm{Na}_{2} \mathrm{~B}_{4} \mathrm{O}_{7}\right)$ or $\mathrm{CuO} / \mathrm{SiO}_{2}$. In another work reported by Wieland et al. [2], they proposed that impregnating boric acid on $\mathrm{CsX}$ could effectively promote the side-chain alkylation activity by neutralizing some unfavorable strong basic sites, which are the main active centers for rapidly decomposing methanol to byproducts like $\mathrm{CO}$ and $\mathrm{H}_{2}$. In our recent work [19], it was found that the modification of $\mathrm{CsX}$ with boron phosphate can improve the catalytic activity for the side-chain alkylation of toluene with methanol. The introduction of $\mathrm{BPO}_{4}$ can bring more weak acidic sites and decrease the concentration of basic sites of the catalysts, which can inhibit the generation of the unfavorable bidentate formate, thus finally resulting in the improvement of the catalytic performance of the catalyst. Currently, it is still a very attractive subject to search easily available and efficient additives for enhancing the side-chain alkylation performance of the CsX catalysts, and to understand the effect of the additives on the acidic-basic properties of the catalysts, as well as on the adsorption/activation ability for methanol and/or toluene.

In this work, some Fe-modified CsX catalysts were prepared by using two kinds of iron resources, $\mathrm{Fe}\left(\mathrm{NO}_{3}\right)_{3}$ and $\mathrm{FeCl}_{3}$, as additives. Their catalytic properties were investigated for the side-chain alkylation of toluene with methanol. By combining a variety of characterization means, including the in situ Fourier-transform infrared spectra (FT-IR) and temperature programmed desorption (TPD) techniques (monitored by a mass spectrometer), the effects of different Fe additives on the acidic-basic property and the adsorption/activation ability of the CsX catalysts were studied for getting some useful information to understand the enhanced role of Fe additives in the side-chain alkylation of toluene with methanol.

\section{Results}

\subsection{Catalytic Performance}

The catalytic properties of CsX and the Fe-modified CsX catalysts for the side-chain alkylation of toluene with methanol are shown in Table 1. The major reaction products are ethylbenzene and styrene, while the byproducts include carbon monoxide, hydrogen, carbon dioxide, xylenes, trimethylbenzene, benzene, and C1-C3-light hydrocarbons. 
Table 1. Catalytic properties of Fe-modified Cs ion-exchanged X zeolite (CsX) catalysts for the side-chain alkylation of toluene with methanol. ${ }^{\text {a }}$

\begin{tabular}{|c|c|c|c|c|c|}
\hline \multirow{2}{*}{ Catalysts } & \multirow{2}{*}{$\begin{array}{c}\text { Conversion } \\
\text { (\%) } \\
\text { Toluene }\end{array}$} & \multicolumn{3}{|c|}{ Selectivity (\%) } & \multirow{2}{*}{$\begin{array}{c}\text { Yield (\%) } \\
\text { Styrene + } \\
\text { Ethylbenzene }\end{array}$} \\
\hline & & Styrene & Ethylbenzene & Others $^{b}$ & \\
\hline Cs $X$ & 6.5 & 19.2 & 78.0 & 2.8 & 6.3 \\
\hline $0.08 \mathrm{Fe} / \mathrm{Cs} X-I$ & 7.8 & 13.3 & 83.5 & 3.2 & 7.6 \\
\hline $0.15 \mathrm{Fe} / \mathrm{CsX}-I$ & 8.0 & 12.4 & 84.5 & 3.1 & 7.6 \\
\hline $0.30 \mathrm{Fe} / \mathrm{CsX}-I$ & 7.0 & 11.2 & 85.1 & 3.7 & 6.7 \\
\hline $0.50 \mathrm{Fe} / \mathrm{CsX}-I$ & 4.9 & 10.5 & 85.2 & 4.3 & 4.7 \\
\hline $0.08 \mathrm{Fe} / \mathrm{CsX}-I I$ & 3.5 & 49.0 & 49.3 & 1.8 & 3.4 \\
\hline $0.15 \mathrm{Fe} / \mathrm{Cs} X-I I$ & 2.7 & 52.8 & 42.6 & 4.6 & 2.5 \\
\hline $0.30 \mathrm{Fe} / \mathrm{CsX}-I I$ & 2.1 & 56.6 & 39.4 & 4.0 & 2.1 \\
\hline
\end{tabular}

a Reaction condition: reaction temperature of $435^{\circ} \mathrm{C}$, reactant space velocity of $2.0 \mathrm{~h}^{-1}$, toluene/methanol ratio of $3 / 1$, reaction time of $2 \mathrm{~h} .{ }^{b}$ Other byproducts include xylenes, trimethylbenzene, and benzene.

A $6.5 \%$ conversion of toluene is obtained over CsX with $19.2 \%$ selectivity to styrene and $78.0 \%$ selectivity to ethylbenzene. Varying the addition amounts of iron $\left(\mathrm{Fe}\left(\mathrm{NO}_{3}\right)_{3}\right.$ or $\left.\mathrm{FeCl}_{3}\right)$ in the range of $0.08-0.50 \mathrm{wt} . \%$ brings significant changes in toluene conversion and selectivity to styrene. For the $\mathrm{Fe}\left(\mathrm{NO}_{3}\right)_{3}$-modified catalysts ( $\left.\mathrm{nFe} / \mathrm{Cs} \mathrm{C}-\mathrm{I}\right)$, introduction of a small amount of Fe species could improve the catalytic activities of the $\mathrm{CsX}$ catalysts. Among them, $0.15 \mathrm{Fe} / \mathrm{CsX}-\mathrm{I}$, derived from the impregnation of CsX with 0.15 wt. \% iron, exhibits the highest toluene conversion (8.0\%) with $84.5 \%$ selectivity of ethylbenzene and $12.4 \%$ selectivity of styrene. With further increasing iron contents, the conversion of toluene decreases gradually, and a $4.9 \%$ conversion of toluene is obtained when the iron loading reaches $0.50 \mathrm{wt} . \%$.

As for the $\mathrm{FeCl}_{3}$-modified CsX catalysts (nFe/CsX-II), the addition of $\mathrm{FeCl}_{3}$ could result in an obvious decrease in toluene conversion, but could indeed improve the selectivity of styrene. It is worth noting that the conversion of methanol decreases to $\sim 90 \%$ when using Fe/CsX-II as a catalyst, lower than $\mathrm{CsX}$ and $\mathrm{Fe} / \mathrm{Cs} \mathrm{X}-\mathrm{I}$ ( $97 \%$ conversion of methanol), implying that the activation ability for methanol decreases somewhat after modifying the $\mathrm{CsX}$ catalyst with $\mathrm{FeCl}_{3}$.

Additional experimental results suggest that the stability of the $\mathrm{Fe}\left(\mathrm{NO}_{3}\right)_{3}$-modified CsX catalyst is better than the unmodified CsX catalyst, and no obvious decrease in catalytic activity could be observed after a 6 - $\mathrm{h}$ reaction over the catalyst of $0.15 \mathrm{Fe} / \mathrm{CsX}$, while a slight decrease for CsX could be detected after $5 \mathrm{~h}$. The gradual deactivation of the CsX catalyst should be mainly caused by the rapid coke deposition over the stronger basic sites of the catalyst, and its catalytic activity could be fully recovered via calcination of the used catalyst at $600^{\circ} \mathrm{C}$ under air.

The above results suggest that modification of $\mathrm{CsX}$ with a suitable amount of $\mathrm{Fe}\left(\mathrm{NO}_{3}\right)_{3}$ as an iron source may improve the catalytic activity for the side-chain alkylation of toluene with methanol. While the modification of $\mathrm{CsX}$ with a small amount of $\mathrm{FeCl}_{3}$ can lead to a considerable decrease in toluene conversion, it can be of benefit to enhance the selectivity of styrene. For understanding the role of the different iron additives, a variety of characterization means were carried out, and the main results are given below.

\subsection{Catalyst Characterization}

Figure 1 shows the $\mathrm{X}$-ray diffraction (XRD) patterns of the $\mathrm{CsX}$, nFe/CsX-I, and nFe/CsX-II catalysts. The diffractograms of the Fe-modified CsX catalysts indicate that the faujasite (FAU) structure of the zeolites is retained after the modification. The appearance of a weak peak at about $12.3^{\circ}$ on the pattern of CsX may be assigned to the formation of some large cesium oxide clusters on the surface of zeolite X [20]. Upon the introduction of Fe species, the signal at $12.3^{\circ}$ decreases gradually, and is nearly undetectable when a relatively high amount of Fe species is introduced. These results suggest that some interactions between the Fe additives and the surface dispersed $\mathrm{Cs}_{2} \mathrm{O}$ clusters should exist. 
The absence of diffraction peaks related to Fe-based compounds indicates the Fe species should be highly dispersed on the zeolite host. In addition, with the increase in Fe content, the intensities of the relevant diffraction peaks belonging to zeolites decrease somewhat. These phenomena can be mainly attributed to the changes in the X-ray absorption coefficients caused by the introduction of Fe-based compounds [15].
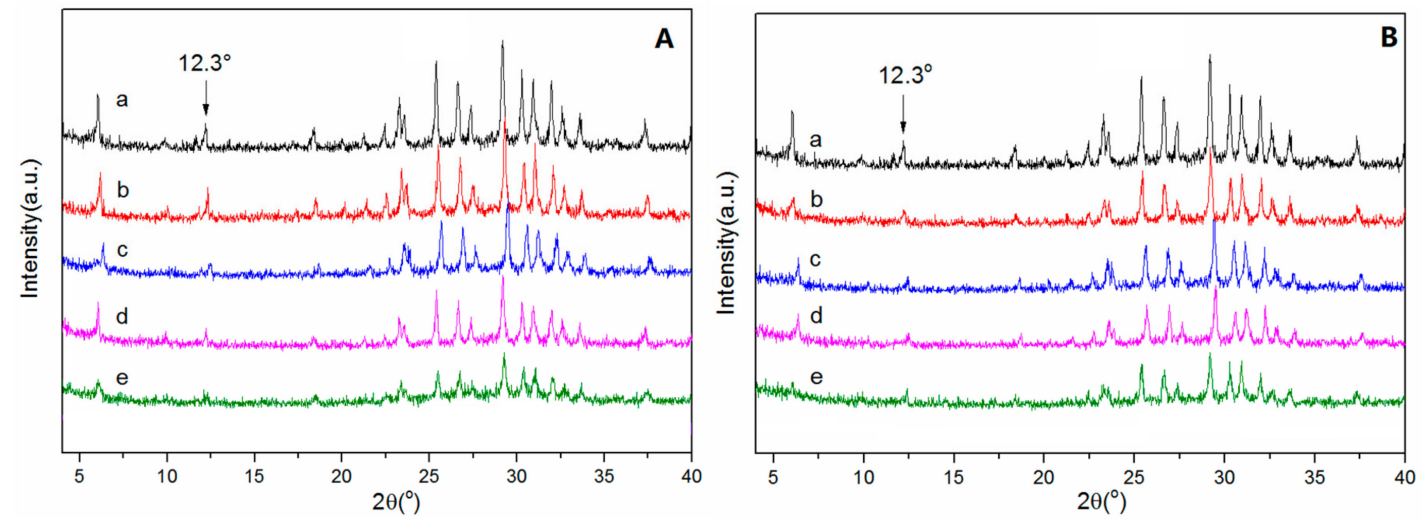

Figure 1. X-ray diffraction (XRD) patterns of the catalysts: (A) (a) Cs ion-exchanged X zeolite (CsX), (b) $0.08 \mathrm{Fe} / \mathrm{CsX}-I$, (c) $0.15 \mathrm{Fe} / \mathrm{CsX}-I$, (d) $0.30 \mathrm{Fe} / \mathrm{CsX}-I$, (e) $0.50 \mathrm{Fe} / \mathrm{CsX}-\mathrm{I}$; (B) (a) CsX, (b) $0.08 \mathrm{Fe} / \mathrm{CsX}-I I$, (c) $0.15 \mathrm{Fe} / \mathrm{CsX}-I I$, (d) $0.30 \mathrm{Fe} / \mathrm{CsX}-I I$, (e) $0.50 \mathrm{Fe} / \mathrm{CsX}-I I$.

Figure 2 shows the SEM images of the CsX, 0.15 Fe/CsX-I, and 0.15 Fe/CsX-II catalysts. The image of the CsX catalyst contains homogeneous zeolite crystal particles with an average size of 2-3 $\mu \mathrm{m}$. The Fe-modified CsX catalysts are composed mostly of similar zeolite crystallites, as well as a trace amounts of small particles below $0.5 \mu \mathrm{m}$. These small particles might contain debris of the $\mathrm{X}$ zeolite crystallites and the Fe-based species. Furthermore, modification of CsX with Fe species could result in a color change from white to pale yellow.
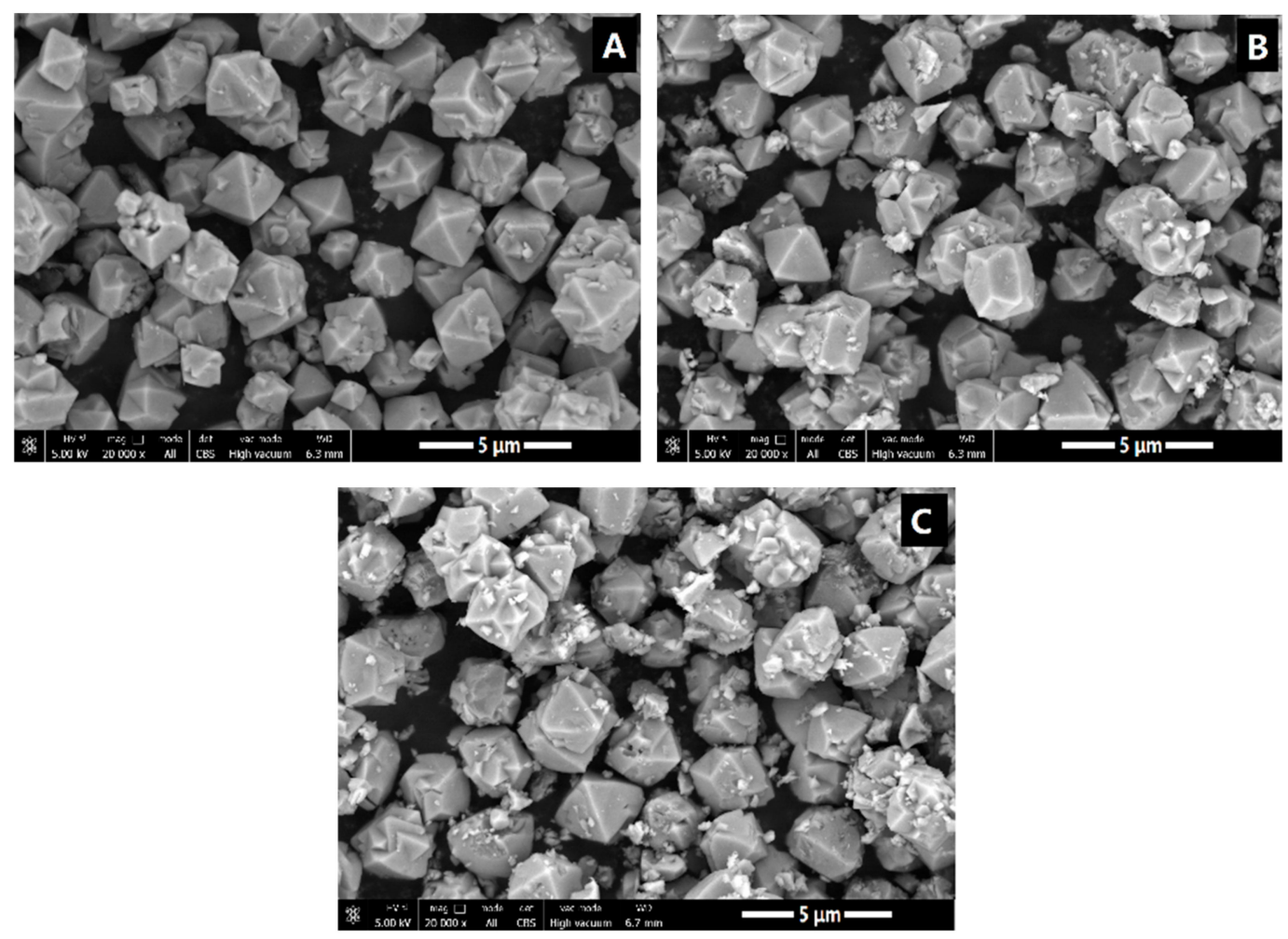

Figure 2. SEM images of catalysts: (A) CsX, (B) $0.15 \mathrm{Fe} / \mathrm{CsX}-I$, (C) $0.15 \mathrm{Fe} / \mathrm{CsX}-I I$. 
In addition, the energy-dispersive spectroscopy (EDS) mappings of CsX, $0.15 \mathrm{Fe} / \mathrm{CsX}-\mathrm{I}$, and $0.15 \mathrm{Fe} / \mathrm{CsX}-\mathrm{II}$ catalysts are shown in Figure 3, which reveal the homogeneous distribution of Cs and Fe species within the zeolite crystals.

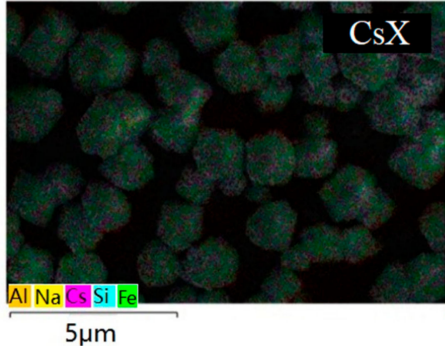

Cs L $\alpha 1$
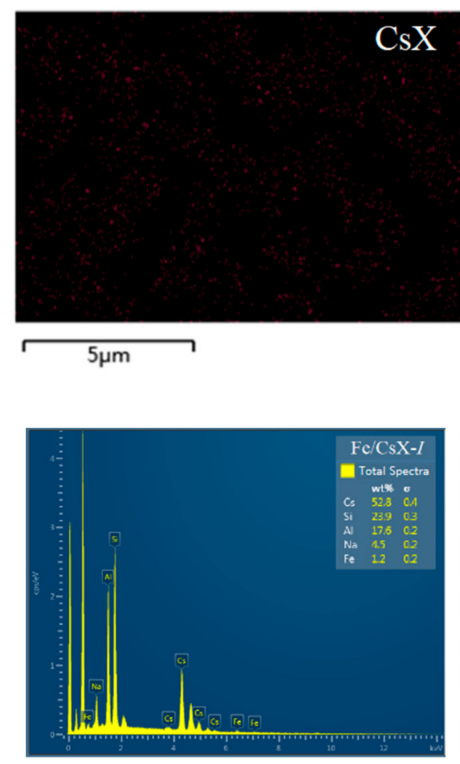

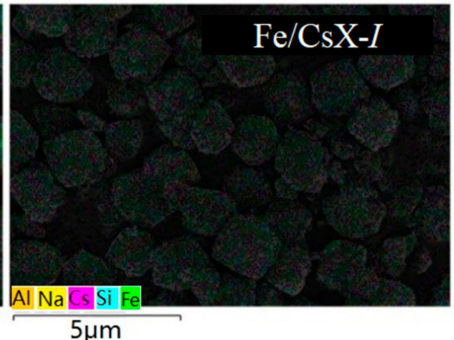

Cs L $\alpha 1$

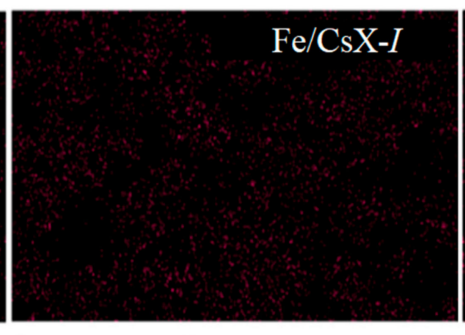

$5 \mu \mathrm{m}$

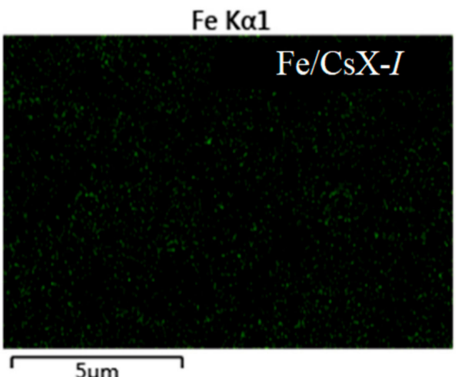

$5 \mu \mathrm{m}$

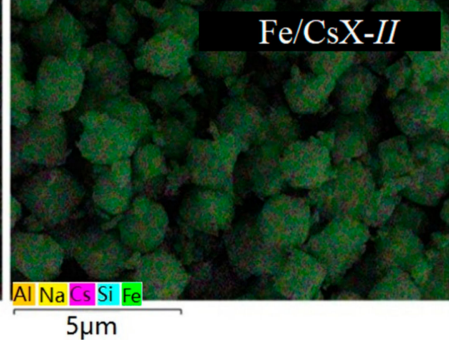

Cs L $\alpha 1$

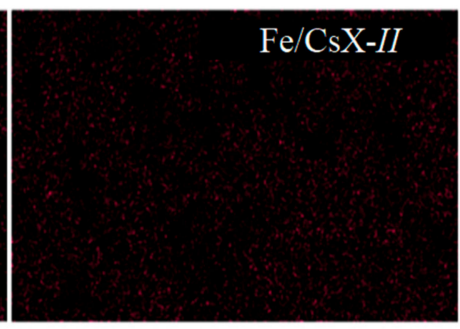

$5 \mu \mathrm{m}$

Fe K $\alpha 1$

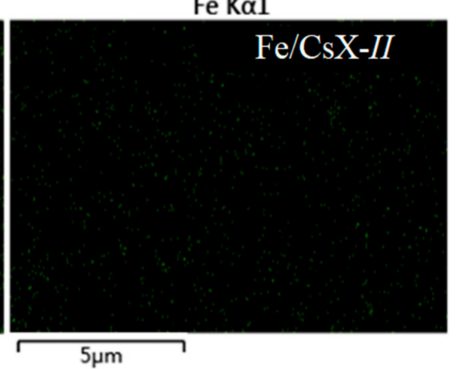

Figure 3. The Cs and Fe element distributions on CsX, 0.15 Fe/CsX-I, and 0.15 Fe/CsX-II derived from the energy-dispersive spectroscopy (EDS) mapping.

The textural parameters of the representative catalysts are listed in Table 2. There is no obvious change in the specific surface areas and the pore parameters between the CsX catalyst and the Fe-modified CsX catalysts due mainly to the relatively low Fe loading. The relatively consistent textural parameters of these catalysts provide further evidence that the crystal structure of $\mathrm{X}$ zeolites is maintained after introducing a certain amount of Fe species.

Table 2. The textural parameters of different catalysts. BET-Brunauer-Emmett-Teller.

\begin{tabular}{|c|c|c|c|c|c|c|}
\hline Catalysts & $\begin{array}{c}\text { BET Surface } \\
\text { Area } \\
\left(\mathrm{m}^{2} / \mathrm{g}\right)\end{array}$ & $\begin{array}{c}\text { Micropore } \\
\text { Area } \\
\left(\mathrm{m}^{2} / \mathrm{g}\right)\end{array}$ & $\begin{array}{c}\text { External } \\
\text { Surface Area } \\
\left(\mathrm{m}^{2} / \mathrm{g}\right)\end{array}$ & $\begin{array}{l}\text { Micropore } \\
\text { Volume } \\
\left(\mathrm{cm}^{3} / \mathrm{g}\right)\end{array}$ & $\begin{array}{l}\text { Total Pore } \\
\text { Volume } \\
\left(\mathrm{cm}^{3} / \mathrm{g}\right)\end{array}$ & $\begin{array}{l}\text { Average } \\
\text { Pore Width } \\
\text { (nm) }\end{array}$ \\
\hline CsX & 324 & 301 & 23 & 0.14 & 0.17 & 1.9 \\
\hline $0.15 \mathrm{Fe} / \mathrm{Cs} X-I$ & 329 & 307 & 22 & 0.15 & 0.18 & 2.0 \\
\hline $0.15 \mathrm{Fe} / \mathrm{CsX}-I$ & 308 & 282 & 24 & 0.13 & 0.16 & 1.9 \\
\hline
\end{tabular}

The $\mathrm{NH}_{3}$-TPD profiles of CsX, 0.15 Fe/CsX-I, and 0.15 Fe/CsX-II are shown in Figure 4A. One major desorption peak of $\mathrm{NH}_{3}$ at around $210{ }^{\circ} \mathrm{C}$ is observed for all the catalysts, which is an indication of the presence of acidic sites with moderate strength. The peak area of $\mathrm{NH}_{3}$ desorption decreases obviously after the introduction of Fe species. For $0.15 \mathrm{Fe} / \mathrm{CsX}-\mathrm{I}$, the peak position shifts slightly toward higher 
temperatures, indicating the appearance of some new acidic centers related to Fe species. Figure $4 \mathrm{~B}$ illustrates the $\mathrm{CO}_{2}$-TPD profiles of the representative catalysts, which shows a broad $\mathrm{CO}_{2}$ desorption peak at around $200{ }^{\circ} \mathrm{C}$, corresponding to basic centers with intermediate strength. Introducing a small amount of Fe species $(0.15 \mathrm{wt} . \%)$ results in a decrease in the number of basic sites. Compared with the $\mathrm{Fe}\left(\mathrm{NO}_{3}\right)_{3}$-modified $\mathrm{CsX}$ catalyst, a more significant decrease can be observed on the $\mathrm{FeCl}_{3}$-modified CsX catalyst. For the $C$ s ion-exchanged $X$ catalyst, it is well known that the basic sites are mainly related to the framework oxygen species of $\mathrm{X}$ zeolites, as well as the oxygen species of $\mathrm{Cs}_{2} \mathrm{O}$. Our current results suggest that modification of $\mathrm{CsX}$ with a certain amount iron salts $\left(\mathrm{Fe}\left(\mathrm{NO}_{3}\right)_{3}\right.$ or $\left.\mathrm{FeCl}_{3}\right)$ could decrease the numbers of both the acidic and basic centers of the catalysts. Such changes should mainly originate from the interaction between the introduced Fe species and the acid-basic sites in the CsX catalyst $[21,22]$.
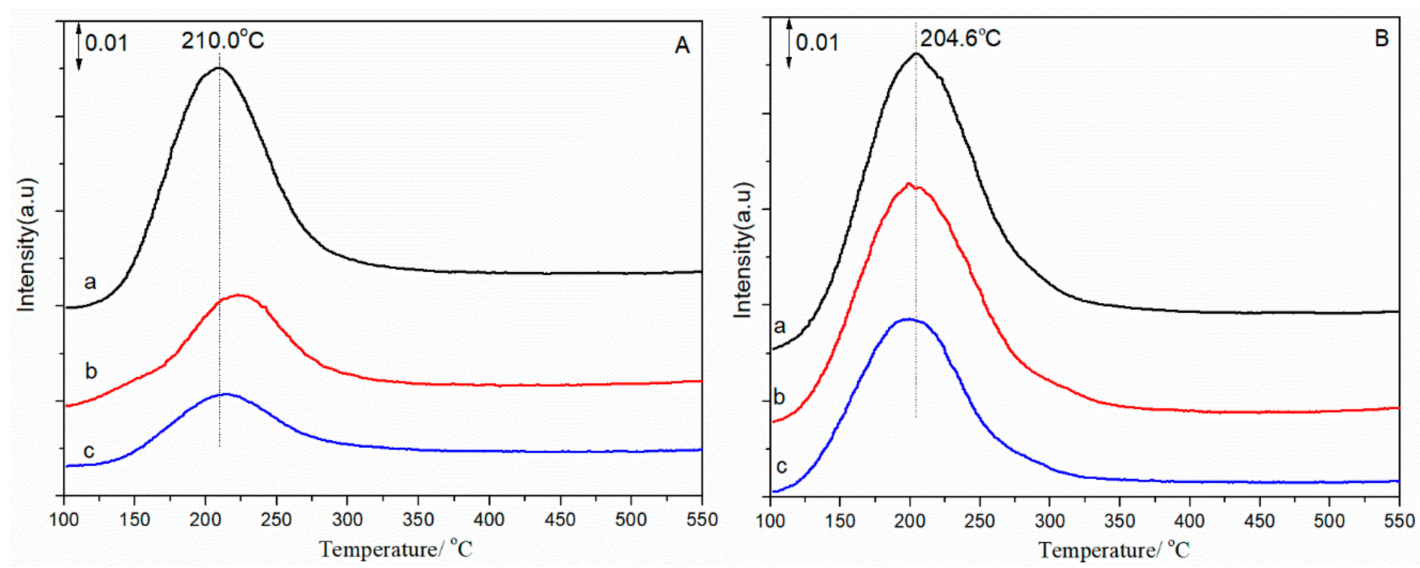

Figure 4. Profiles of (A) $\mathrm{NH}_{3}$ temperature programmed desorption (TPD) and (B) $\mathrm{CO}_{2}-\mathrm{TPD}$ for catalysts: (a) CsX, (b) $0.15 \mathrm{Fe} / \mathrm{CsX}-I$, (c) $0.15 \mathrm{Fe} / \mathrm{CsX}-I I$.

For $0.15 \mathrm{Fe} / \mathrm{CsX}-\mathrm{II}$, the obvious decrease in basic sites should be an indication that $\mathrm{FeCl}_{3}$ has a stronger ability to neutralize or cover more basic sites in the CsX catalyst [21,23]. Previous literature results already revealed that the basic sites of CsX zeolites are the main active sites for the side alkylation reaction of toluene with methanol [15-17,24-26]. Therefore, the significant decrease in catalytic activity of the $\mathrm{FeCl}_{3}$-modified $\mathrm{CsX}$ should be due mainly to the considerable loss in the number of basic sites.

\subsection{The Adsorption and Desorption Behaviors of the Reagents on the Catalysts}

In order to understand the main reason for why the two types of Fe-modified catalysts showed different catalytic activity and selectivity in the side-chain alkylation reaction, the adsorption/desorption properties of $0.15 \mathrm{Fe} / \mathrm{CsX}-\mathrm{I}$ and $0.15 \mathrm{Fe} / \mathrm{CsX}-\mathrm{II}$ for methanol or toluene were investigated by using in situ FT-IR measurement and TPD mass techniques.

The FT-IR spectra of methanol absorbed on CsX at $140{ }^{\circ} \mathrm{C}$ are shown in Figure 5. The strong band at $1693 \mathrm{~cm}^{-1}$ is attributed to the $\mathrm{C}=\mathrm{O}$ stretching vibration of formaldehyde [27]. The sharp band at $1290 \mathrm{~cm}^{-1}$ should be also related to formaldehyde, due to its relative intensity being consistent with the signal of $1693 \mathrm{~cm}^{-1}$ at different operation conditions. The two bands appearing at 1649 and $1379 \mathrm{~cm}^{-1}$ could be assigned to the stretching vibrations of $\mathrm{C}=\mathrm{O}$ and $\mathrm{C}-\mathrm{O}$ in surface-adsorbed unidentate formate $[27,28]$, while the signals at 1609 and $1339 \mathrm{~cm}^{-1}$ (weak) are assigned to asymmetric and symmetric $\mathrm{O}-\mathrm{C}-\mathrm{O}$ stretching modes of the adsorbed bidentate formate [27]. Previous literature works revealed that unidentate formate derived from the further activation of formaldehyde is the main active intermediate for the side-chain alkylation reaction, while bidentate formate is an undesirable intermediate, which is mainly related to the formation of $\mathrm{CO}$ and $\mathrm{H}_{2}$ [29]. 


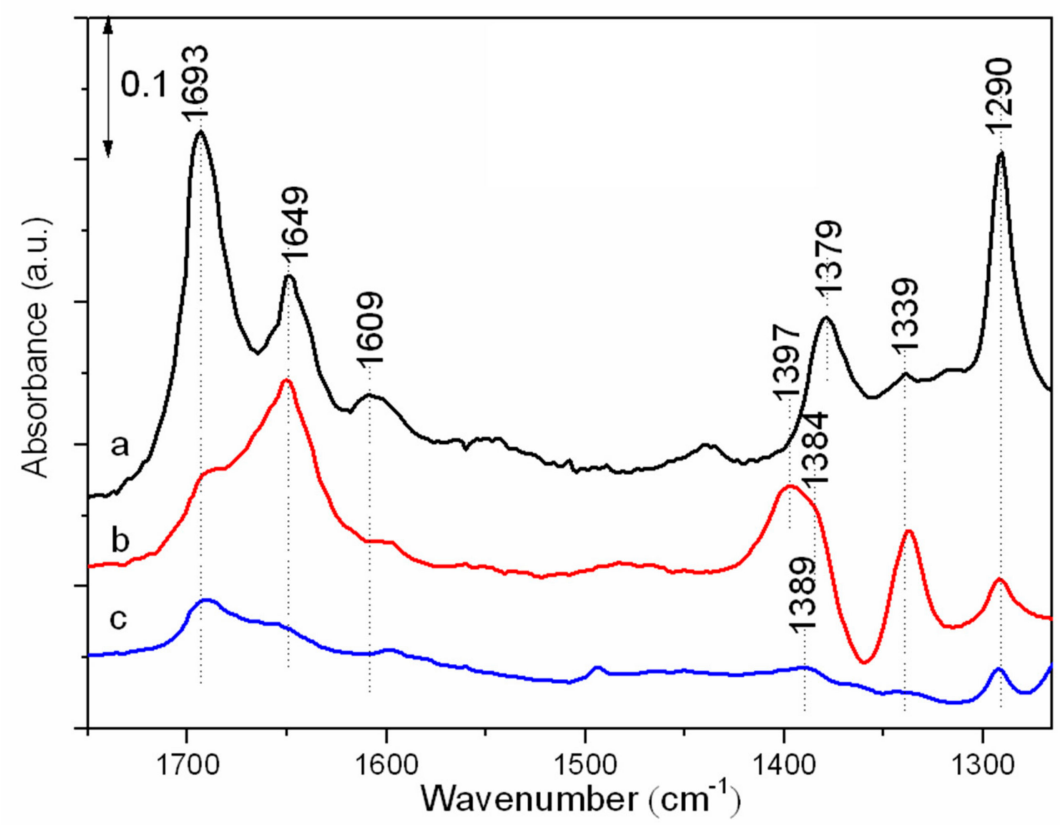

Figure 5. Fourier-transform infrared (FT-IR) spectra of surface species remaining on (a) CsX, (b) $0.15 \mathrm{Fe} / \mathrm{CsX}-\mathrm{I}$, and (c) $0.15 \mathrm{Fe} / \mathrm{CsX}-\mathrm{II}$ after exposure to $1000 \mathrm{~Pa}$ methanol at $50{ }^{\circ} \mathrm{C}$ for $30 \mathrm{~min}$ and subsequent sequential evacuation at $140{ }^{\circ} \mathrm{C}$.

Compared with the CsX catalyst, the FT-IR spectra of the surface-adsorbed species exhibit obvious changes over $0.15 \mathrm{Fe} / \mathrm{CsX}-I$ and $0.15 \mathrm{Fe} / \mathrm{CsX}-\mathrm{II}$. The intensities of the two bands at 1693 and $1290 \mathrm{~cm}^{-1}$ related to formaldehyde decrease significantly in the spectrum of $0.15 \mathrm{Fe} / \mathrm{Cs} X-I$. The band at $1650 \mathrm{~cm}^{-1}$ $\left(v_{\mathrm{C}=\mathrm{O}}\right.$ unidentate formate) is also observed for $0.15 \mathrm{Fe} / \mathrm{CsX}-\mathrm{I}$, but the signal of bidentate formate $\left(1609 \mathrm{~cm}^{-1}\right)$ is nearly undetectable. These results suggest that modification of CsX with a small amount of $\mathrm{Fe}\left(\mathrm{NO}_{3}\right)_{3}$ (i.e., $0.15 \mathrm{wt}$.\% $\mathrm{Fe}$ ) is favorable for the formation of the unidentate formate, while it can significantly inhibit the formation of bidentate formate.

In the case of $0.15 \mathrm{Fe} / \mathrm{CsX}-\mathrm{II}$, the intensities of the bands 1693 and $1290 \mathrm{~cm}^{-1}$ are also significantly reduced, indicating that only a small amount of formaldehyde is generated after the adsorption of methanol. Meanwhile, the stretching vibration bands $1649 \mathrm{~cm}^{-1}$ and $1609 \mathrm{~cm}^{-1}$ are absent in the methanol adsorbed spectrum. These results suggest that the amount of adsorbed formaldehyde, which derives from the activation of methanol, decreases significantly after adding a small amount of $\mathrm{FeCl}_{3}(0.15 \mathrm{wt}$.\% Fe) into the $\mathrm{CsX}$ catalyst. Moreover, the formation of formates is also considerably suppressed over the $\mathrm{FeCl}_{3}$-modified CsX catalyst.

The methanol TPD profiles over CsX and the Fe-modified CsX catalysts are shown in Figure 6. The gas phase analysis based on a quadrupole mass spectrometer reveals the presence of $\mathrm{H}_{2}, \mathrm{CH}_{4}, \mathrm{CO}$, and $\mathrm{HCHO}$ during the temperature programmed desorption process of methanol. It can be seen that the gas products start to appear at $314^{\circ} \mathrm{C}$ on the $\mathrm{CsX}$ catalyst (see Figure 7A). The intensities of $\mathrm{CH}_{4}$ and $\mathrm{HCHO}$ reach the maximum at around $410{ }^{\circ} \mathrm{C}$. The signal of $\mathrm{CO}_{2}$ starts at $349^{\circ} \mathrm{C}$, showing two maxima peaks at 397 and $511^{\circ} \mathrm{C}$, respectively. The profiles of $\mathrm{CO}$ and $\mathrm{H}_{2}$ also exhibit two maxima peaks at 410 and $520^{\circ} \mathrm{C}$, respectively. These results suggest that at least two kinds of active sites (basic centers) are present on the surface of CsX catalyst, which could participate in the activation of methanol separately. As for $0.15 \mathrm{Fe} / \mathrm{CsX}-\mathrm{I}$, the decomposition of methanol starts at about $330^{\circ} \mathrm{C}$, slightly higher than that of CsX. Additionally, the TPD profiles show only one single maximum peak for each product. These results imply that the addition of Fe species could cover or neutralize some stronger basic sites for methanol activation. The concentrations of $\mathrm{CH}_{4}$ and $\mathrm{HCHO}$ reach the maximum at around $426^{\circ} \mathrm{C}$, and gaseous $\mathrm{CO}_{2}$ is detected with a maximum at $522{ }^{\circ} \mathrm{C}$. The peaks of $\mathrm{CO}$ and $\mathrm{H}_{2}$ appear at $480{ }^{\circ} \mathrm{C}$ in the desorption profiles. For the catalyst of $0.15 \mathrm{Fe} / \mathrm{CsX}-\mathrm{II}$, gaseous $\mathrm{CO}$ and $\mathrm{H}_{2}$ are detected at around 
$400{ }^{\circ} \mathrm{C}$, while a $\mathrm{CO}_{2}$ peak appears at $470{ }^{\circ} \mathrm{C}$. Gas phase analysis results reveal that $0.15 \mathrm{Fe} / \mathrm{CsX}-\mathrm{II}$ has a much lower ability for methanol activation compared to CsX and $0.15 \mathrm{Fe} / \mathrm{CsX}-\mathrm{I}$ catalysts.
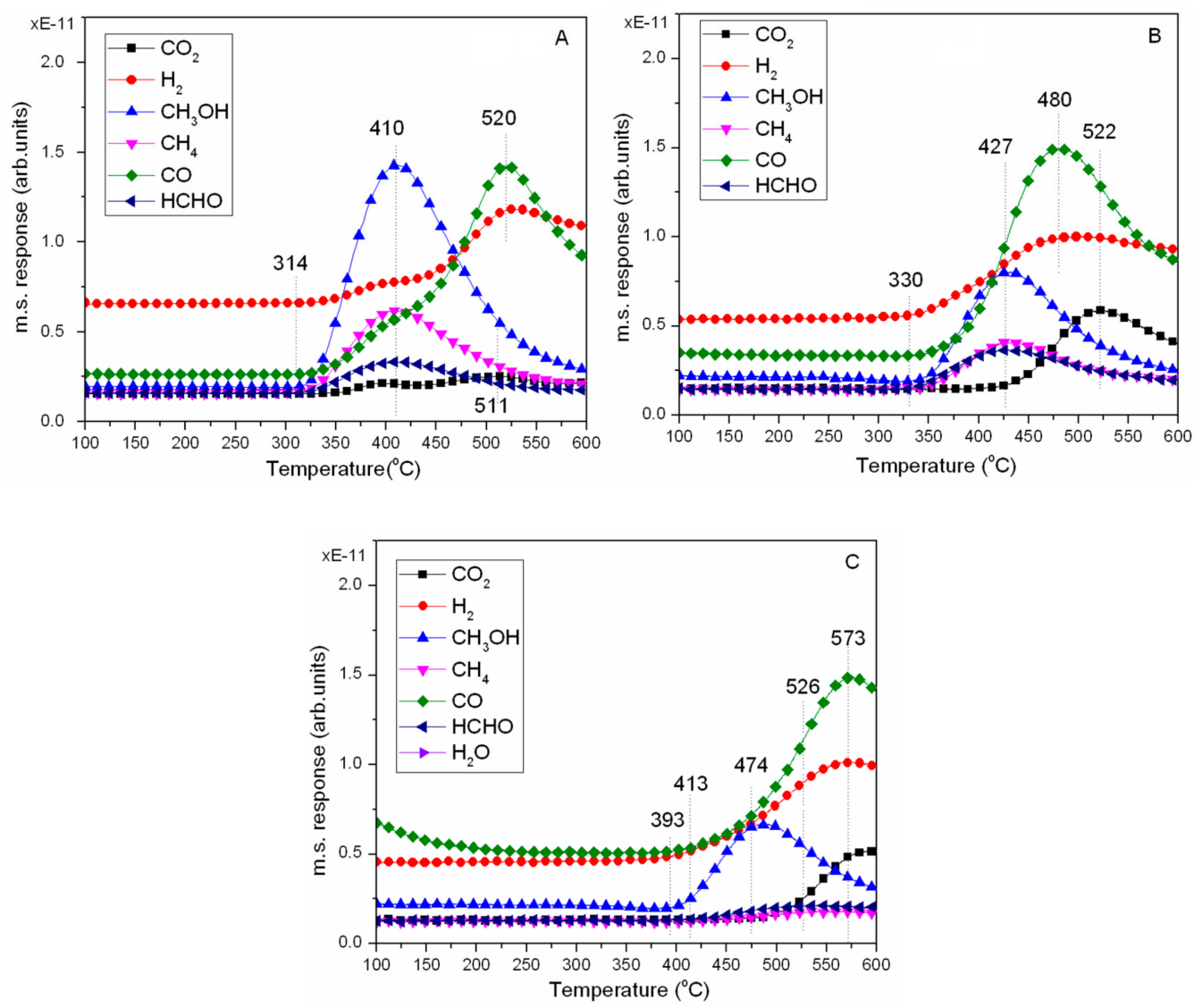

Figure 6. The methanol TPD profiles over various catalysts: (A) CsX, (B) $0.15 \mathrm{Fe} / \mathrm{CsX}-\mathrm{I}$, (C) $0.15 \mathrm{FeCsX}-I I$.
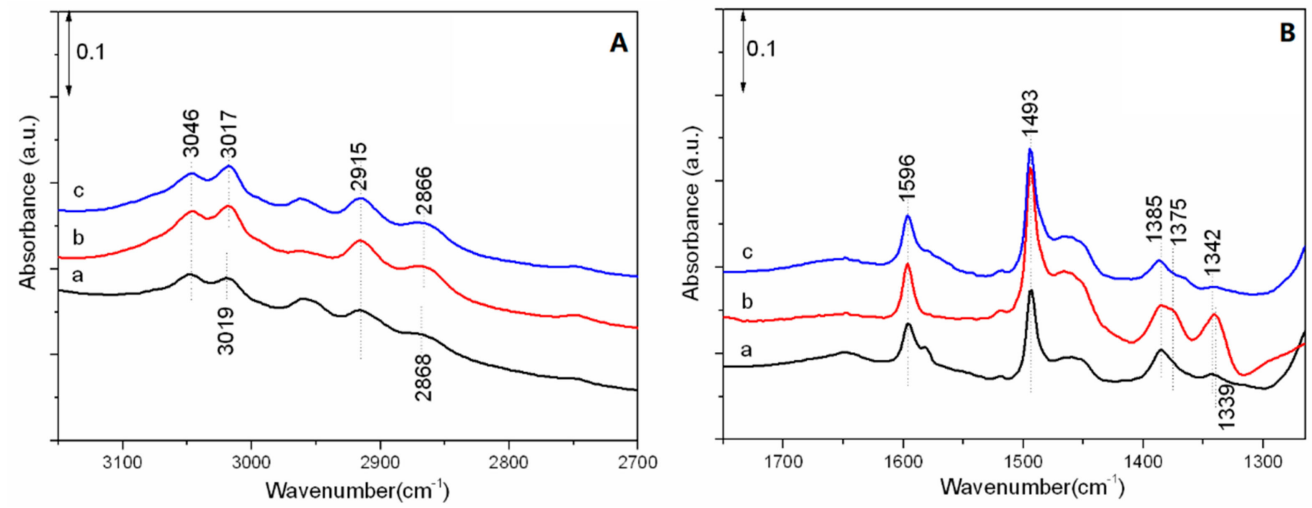

Figure 7. FT-IR spectra of surface species remaining on (a) CsX, (b) $0.15 \mathrm{Fe} / \mathrm{CsX}-\mathrm{I}$, and (c) $0.15 \mathrm{Fe} / \mathrm{CsX}-\mathrm{II}$ after exposure to $1000 \mathrm{~Pa}$ toluene at $50^{\circ} \mathrm{C}$ for $30 \mathrm{~min}$ and subsequent sequential evacuation at $140{ }^{\circ} \mathrm{C}$, (A) Wavenumber range in $3150-2700 \mathrm{~cm}^{-1}$, (B) Wavenumber range in $1750-12500 \mathrm{~cm}^{-1}$.

For the side-chain alkylation of toluene with methanol, it is believed that the formation of undesirable $\mathrm{CO}_{x}\left(\mathrm{CO}\right.$ and $\left.\mathrm{CO}_{2}\right)$ is mainly facilitated by the stronger basic sites existing on the CsX catalyst through the following steps: methanol dehydrogenation occurs on the basic sites to intermediately form formaldehyde ( $\mathrm{HCHO}$ ); then, $\mathrm{HCHO}$ is transformed to surface formates, which subsequently decompose into $\mathrm{H}_{2}, \mathrm{CO}_{2}$, and $\mathrm{CO}$. Moreover, the further methanization of $\mathrm{CO}$ with $\mathrm{H}_{2}$ is responsible for the formation of $\mathrm{CH}_{4}$ [30]. In our case, the introduction of $\mathrm{Fe}\left(\mathrm{NO}_{3}\right)_{3}$ into the 
CsX catalyst can efficiently inhibit the undesirable decomposition of methanol, while loading with $\mathrm{FeCl}_{3}$ can significantly suppress the formation of the intermediates like formaldehyde and/or formates.

The FT-IR spectra of the toluene adsorption on various catalysts are compiled in Figure 7. For CsX, the bands observed at 1596 and $1493 \mathrm{~cm}^{-1}$ can be assigned to the stretching vibrations of $\mathrm{C}-\mathrm{C}$ and $\mathrm{C}=\mathrm{C}$ in surface-adsorbed toluene [31,32]. The two bands at 3047 and $3019 \mathrm{~cm}^{-1}$ are related to the C-H stretching vibration bands of the aromatic ring. The peaks appearing at 2915 and $2865 \mathrm{~cm}^{-1}$ are attributed to the $\mathrm{C}-\mathrm{H}$ stretching of the methyl group of toluene [33]. These results suggest that toluene could be physically adsorbed on the surface of CsX catalyst [34]. For the two Fe-modified CsX catalysts, the main signals related to the $\mathrm{C}-\mathrm{H}$ stretching vibrations of the aromatic ring and the methyl group are quite similar to the $\mathrm{CsX}$ catalysts, indicating that the activating ability for toluene does not have obvious changes after introducing a small amount of Fe additives into the CsX catalyst.

The temperature programmed desorption of toluene over the catalysts is shown in Figure 8. For all the catalysts, a weak shoulder peak appears at around $108{ }^{\circ} \mathrm{C}$, while the main desorption peak is detected at about $260^{\circ} \mathrm{C}$. Compared with CsX, the main peak shifts slightly toward lower temperatures for $0.15 \mathrm{Fe} / \mathrm{CsX}-\mathrm{I}$ and $0.15 \mathrm{Fe} / \mathrm{CsX}-\mathrm{II}$ catalysts. Furthermore, the total amounts of the desorbed toluene follow the order of $\mathrm{CsX}>0.15 \mathrm{Fe} / \mathrm{CsX}-I>0.15 \mathrm{Fe} / \mathrm{Cs} X-I I$. These results suggest that the adsorption ability for toluene decreases a little bit after introducing a small amount of Fe species into the CsX catalyst.

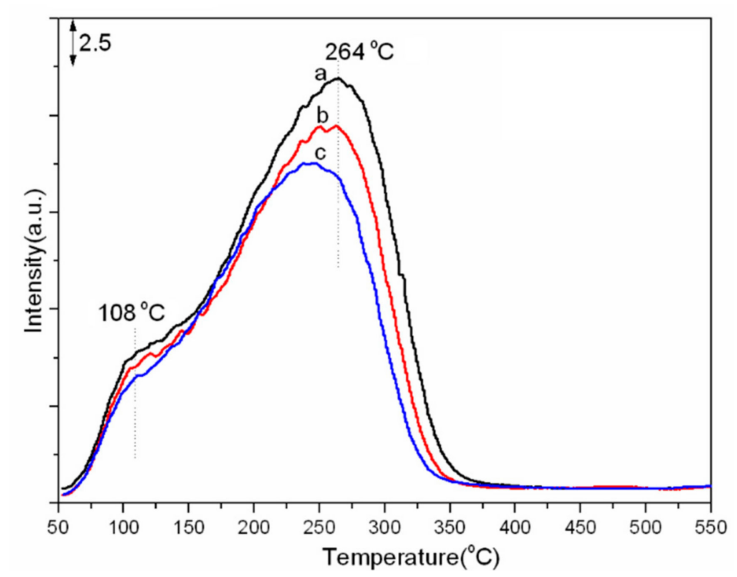

Figure 8. Temperature programmed desorption of toluene over catalysts: (a) CsX, (b) $0.15 \mathrm{Fe} / \mathrm{CsX}-I$, and (c) $0.15 \mathrm{Fe} / \mathrm{CsX}-I I$.

\section{Discussion}

Previous studies revealed that a typical side-chain alkylation catalyst should have basic sites with sufficient strength for achieving the decomposition of methanol to an alkylating agent (like formaldehyde and unidentate formate), and should also have other acidic-basic sites for adsorbing toluene and polarizing its methyl group $[8,24,35]$. Early works also suggested that the presence of a high density of basic sites in the CsX catalyst is related to the transformation of the unidentate formate to bidentate formate, an unfavorable intermediate to be easily transferred to $\mathrm{CO}$ and $\mathrm{H}_{2}$, thus decreasing the utilization of methanol and the yield of side-chain products [29]. Such a problem may be solved to some extent by modification of the ion-exchanged CsX catalyst with additives like boron acid, phosphorous acid, or the corresponding salts through adjusting the acidic-basic properties of the catalyst $[7,9,19]$.

In the present work, a variety of characterization results including TPD and FT-IR measurements suggest that the addition of a small amount of $\mathrm{Fe}\left(\mathrm{NO}_{3}\right)_{3}$ into the $\mathrm{CsX}$ catalyst could cover some basic sites of the catalyst, bringing a certain amount of new Lewis acidic sites of $\mathrm{FeO}_{x}$ (derived from the decomposition of $\left.\mathrm{Fe}\left(\mathrm{NO}_{3}\right)_{3}\right)$. Compared with the unmodified CsX catalyst, the $\mathrm{Fe}\left(\mathrm{NO}_{3}\right)_{3}$-modified catalyst shows better capability in activating methanol to generate real alkylation agents or intermediates 
(i.e., formaldehyde and unidentate formate), and in inhibiting the formation of the unfavorable intermediate of bidentate formate. Therefore, the role of Fe additive in enhancing the catalytic property of $\mathrm{CsX}$ catalyst should also be due mainly to it covering some unfavorable stronger basic sites, similar to the previously reported additive of $\mathrm{BPO}_{4}$ [19]. Additionally, early work reported that the addition of Fe species into Mobil-five (MFI)-type zeolite catalysts may also influence the activation ability of toluene in the alkylation reaction, and the introduced $\mathrm{Fe}_{2} \mathrm{O}_{3}$ could induce the formation of formate via chemisorption of methanol at temperatures above $400 \mathrm{~K}$ [36-38]. Hence, it seems reasonable to propose that the introduced $\mathrm{FeO}_{x}$ (derived from the decomposition of $\mathrm{Fe}\left(\mathrm{NO}_{3}\right)_{3}$ ), which uniformly distributed on the surface of $\mathrm{CsX}$ catalyst, may also act as an efficient active site to directly participate in the adsorption/activation of methanol and toluene.

It should be mentioned here that, although the catalytic activity of $0.15 \mathrm{Fe} / \mathrm{CsX}-\mathrm{I}$ is lower than the literature-reported $\mathrm{ZrB}_{2} \mathrm{O}_{5}$ - or $\mathrm{BPO}_{4}$-modified $\mathrm{CsX}$ catalysts $[9,19]$, it is still a relatively active catalyst in comparison with other additive-modified $\mathrm{CsX}$ catalysts, like $\mathrm{Cs}_{2} \mathrm{O} / \mathrm{CsX}$ [7], $\mathrm{Na}_{2} \mathrm{~B}_{4} \mathrm{O}_{7} / \mathrm{CsX}$ [17], and $\mathrm{ZnO} / \mathrm{CsX}$ [39], suggesting that $\mathrm{Fe}\left(\mathrm{NO}_{3}\right)_{3}$ could functionalize as an effective additive to improve the catalytic performance of the ion-exchanged CsX catalyst. A undesirable feature of the $\mathrm{Fe}\left(\mathrm{NO}_{3}\right)_{3}$-modified $\mathrm{CsX}$ catalyst is that it exhibits relatively low selectivity to styrene, and high selectivity to ethylbenzene. Previous literature results revealed that the reaction of styrene with methanol or hydrogen (decomposed product) is the main pathway to generate ethylbenzene [24,40]. Therefore, the high ethylbenzene selectivity of the $\mathrm{Fe}\left(\mathrm{NO}_{3}\right)_{3}$-modified CsX catalyst should be an indication that the introduced Fe species may also enhance the hydrogenation ability of the catalyst. Further work is still required to improve the catalytic activity and styrene selectivity of the Fe-based CsX catalyst, i.e., by introducing a second ingredient, which is currently underway.

\section{Materials and Methods}

\subsection{Catalyst Preparation}

The commercial $\mathrm{NaX}$ zeolites $(\mathrm{Si} / \mathrm{Al}=1.5)$, purchased from NanKai Catalyst Company, were calcined at $550^{\circ} \mathrm{C}$ for $6 \mathrm{~h}$ in a muffle furnace before the ion-exchange procedure. The CsX catalysts were typically prepared as follows: NaX zeolites $(6 \mathrm{~g})$ were ion-exchanged with $0.2 \mathrm{~mol} / \mathrm{L}(450 \mathrm{~mL})$ aqueous solutions of $\mathrm{CsNO}_{3}$ (from Alading) to replace the $\mathrm{Na}^{+}$with $\mathrm{Cs}^{+}$for $2 \mathrm{~h}$ at $70{ }^{\circ} \mathrm{C}$. The filtered cake was washed with distilled water three times on a vacuum filter and dried in an oven at $100^{\circ} \mathrm{C}$ overnight. The resulting samples were then calcined at $600{ }^{\circ} \mathrm{C}$ (heating rate of $2{ }^{\circ} \mathrm{C} / \mathrm{min}$ ) for $4 \mathrm{~h}$ in flowing air to get $\mathrm{Cs}$ ion-exchanged $\mathrm{X}$ zeolites (CsX).

Iron-modified $\mathrm{Cs} X$ catalysts were prepared by incipient wetness impregnation with an aqueous solution of $\mathrm{Fe}\left(\mathrm{NO}_{3}\right)_{3}$ or $\mathrm{FeCl}_{3}$. The contents of Fe were adjusted by changing the concentration of the Fe salt aqueous solution. After impregnation, the resultant catalysts were dried at $100{ }^{\circ} \mathrm{C}$ and subsequently calcined at $600^{\circ} \mathrm{C}$ in air for $4 \mathrm{~h}$. The iron-modified catalysts were designated as nFe/CsX-I and $\mathrm{nFe} / \mathrm{CsX}-\mathrm{II}$, where $\mathrm{n}$ refers to the wt.\% of iron in the catalysts, and $I$ and $I I$ indicate the iron sources of $\mathrm{Fe}\left(\mathrm{NO}_{3}\right)_{3}$ and $\mathrm{FeCl}_{3}$, respectively.

\subsection{Catalytic Experiments}

The catalytic reactions were carried out in a quartz fixed-bed reactor (8 $\mathrm{mm}$ inner diameter (ID)) under atmospheric pressure. About $0.5 \mathrm{~g}$ of catalyst (40-60 mesh) was packed into the constant temperature zone. Before the reaction, the catalysts were activated at $450{ }^{\circ} \mathrm{C}$ with a heating rate of $10^{\circ} \mathrm{C} / \mathrm{min}$ for $2 \mathrm{~h}$ in a stream of air $(30 \mathrm{~mL} / \mathrm{min})$, and then cooled down to $435^{\circ} \mathrm{C}$. A liquid mixture of toluene and methanol (molar ratio 3/1) was pumped at a rate of $1.2 \mathrm{~mL} / \mathrm{h}$ in a flowing $\mathrm{N}_{2}$ stream $(20 \mathrm{~mL} / \mathrm{min})$. The products were analyzed by a gas chromatograph (BF3420A) connected to a free fatty acid phase (FFAP) capillary column. 


\subsection{Characterization of Catalyst}

Brunauer-Emmett-Teller (BET) surface areas and pore volumes of the samples were measured by $\mathrm{N}_{2}$ adsorption at $-196^{\circ} \mathrm{C}$ using a Micromeritics ASAP 2010N analyzer (Micromeritics instrument Ltd. Shanghai, China). The samples were pretreated under a vacuum at $250{ }^{\circ} \mathrm{C}$ for $12 \mathrm{~h}$ prior to the measurement. The temperature programmed desorption (TPD) of $\mathrm{CO}_{2}$ and $\mathrm{NH}_{3}$ was used to determine the properties of base and acid. The fresh sample (50 mg, 40-60 mesh) was calcined at $550{ }^{\circ} \mathrm{C}$ for $1 \mathrm{~h}$ in $\mathrm{He}$ flow, then cooled down to $100{ }^{\circ} \mathrm{C}$ in order to adsorb $\mathrm{CO}_{2}$ or $\mathrm{NH}_{3}$ for $0.5 \mathrm{~h}$. After the excess $\mathrm{CO}_{2}$ or $\mathrm{NH}_{3}$ was removed by flowing $\mathrm{He}$ for $1 \mathrm{~h}$ at $100^{\circ} \mathrm{C}$, the temperature programmed desorption was carried out at a rate of $10^{\circ} \mathrm{C} / \mathrm{min}$ in $\mathrm{He}(30 \mathrm{~mL} / \mathrm{min})$, and the desorbed $\mathrm{CO}_{2}$ or $\mathrm{NH}_{3}$ was monitored online by a thermal conductivity detector (Micromeritics instrument Ltd. Shanghai, China). The toluene TPD was also obtained using the abovementioned method. Methanol decomposition and desorption were monitored by a quadrupole mass spectrometer (Omni Star ${ }^{\mathrm{TM}}$, Pfeiffer Vacuum Co., Ltd. Shanghai, China). TPD and thermal evolution profiles were recorded by monitoring the intensity of different $m / e$ fragments as a function of temperature. The crystal structures of samples were characterized on a Shimadzu XRD-6000 diffractometer (40 kV and $30 \mathrm{~mA}$ ) (Shimadzu Global Laboratory Consumables Co., Ltd., Shanghai, China) using Ni-filtered $\mathrm{Cu} \mathrm{K} \alpha$ radiation. Scanning electron microscope (SEM) images and EDS mapping were measured with a Hitachi X-65.

The adsorption/activation behaviors of methanol, toluene, or the mixture of toluene/methanol (molar ratio of 3/1) were studied by using an in situ Fourier-transform infrared (FT-IR) spectrometer (Thermo Scientific NicoletTM 6700, Thermo Electron Instruments Co., Shanghai, China). The catalyst powder was pressed into a thin self-supporting wafer $(\sim 15 \mathrm{mg}$, and $13 \mathrm{~mm}$ diameter $)$ and placed in the infrared cell equipped with a $\mathrm{CaF}_{2}$ window, which was attached to a vacuum system. Before the measurement, the samples were evacuated under vacuum at $30{ }^{\circ} \mathrm{C}$ for $1 \mathrm{~h}$ and cooled down to $50{ }^{\circ} \mathrm{C}$. Subsequently, the samples were exposed to reactants (10 mbar) until equilibration for adsorption at $50{ }^{\circ} \mathrm{C}$, and then desorbed under vacuum at $140^{\circ} \mathrm{C}$ for $30 \mathrm{~min}$. The corresponding FT-IR spectra were recorded upon decreasing the temperature to $50^{\circ} \mathrm{C}$ again.

\section{Conclusions}

In the present study, the side-chain alkylation of toluene with methanol was investigated over two kinds of iron-modified $\mathrm{CsX}$ catalysts. Modification with appropriate amounts of $\mathrm{FeO}_{x}$ (derived from $\left.\mathrm{Fe}\left(\mathrm{NO}_{3}\right)_{3}\right)$ has a positive effect on improving the catalytic activity of the CsX catalyst. The introduced $\mathrm{FeO}_{x}$ could cover some unfavorable basic sites, thus inhibiting the generation of undesirable bidentate formate. Furthermore, the surface dispersed $\mathrm{FeO}_{x}$ species may also act as new Lewis acidic sites to participate in the adsorption/activation of toluene, and to stabilize the alkylation intermediate of unidentate formate, finally resulting in an improvement of the catalytic activity of the CsX catalyst for the side-chain alkylation reaction.

Author Contributions: The experimental work was designed and supported by M.J. and C.Z.; X.Y. and S.M. helped formulate the precursors; Z.Z., H.L., and W.S. analyzed the data; M.J. and C.Z. contributed reagents/materials/analysis tools and all material supports. The manuscript was amended and supplemented by all authors. All authors gave approval for the final version of the manuscript.

Funding: The authors greatly appreciate the financial support of the Jilin Institute of Chemical Technology School-level Major Project (No. 2018006) and General Project (No. 2017022), the National Natural Science Foundation of China (No. 21473074), and the Shanghai Engineering Research Center of Green Energy Chemical Engineering (No. 18DZ2254200).

Conflicts of Interest: The authors declare no conflicts of interest.

\section{References}

1. Sidorenko, Y.N.; Galich, P.N.; Gutyrya, V.S. Condensation of toluene and methanol upon synthetic zeolites containing ion-exchange cations of alkali metals. Doklady Akademii Nauk SSSR 1967, 173, 132-134. 
2. Wieland, W.S.; Davis, R.J.; Garces, J.M. Side-Chain Alkylation of Toluene with Methanol over Alkali-Exchanged Zeolites X, Y, L, and ß. J. Catal. 1998, 173, 490-500. [CrossRef]

3. Engelhardt, J.; Szanyi, J.; Valyon, J. Alkylation of toluene with methanol on commercial X zeolite in different alkali cation forms. J. Catal. 1987, 107, 296-306. [CrossRef]

4. Sivasankar, N.; Vasudevan, S. Alkylation of toluene by methanol over alkali exchanged zeolite-X: Side chain versus ring alkylation. J. Indian Inst. Sci. 2010, 90, 231-243.

5. Hunger, M.; Schenk, U.; Seiler, M.; Weitkamp, J. In situ MAS NMR spectroscopy of surface compounds formed from methanol and from a toluene/methanol mixture on basic zeolite X. J. Mol. Catal. A Chem. 2000, 156, 153-161. [CrossRef]

6. Borgna, A.; Magni, S.; Sepulveda, J.; Padro, C.L.; Apesteguia, C.R. Side-chain alkylation of toluene with methanol on Cs-exchanged NaY zeolites: Effect of Cs loading. Catal. Lett. 2005, 102, 15-21. [CrossRef]

7. Alabi, W.O.; Tope, B.B.; Jermy, R.B.; Aitani, A.M.; Hattori, H.; Al-Khattaf, S.S. Modification of Cs-X for styrene production by side-chain alkylation of toluene with methanol. Catal. Today 2014, 226, 117-123. [CrossRef]

8. Philippou, A.; Anderson, M.W. Solid-state NMR investigation of the alkylation of toluene with methanol over basic zeolite X. J. Am. Chem. Soc. 1994, 116, 5774-5783. [CrossRef]

9. Tope, B.B.; Alabi, W.O.; Aitani, A.M.; Hattori, H.; Al-Khattaf, S.S. Side-chain alkylation of toluene with methanol to styrene over cesium ion-exchanged zeolite X modified with metal borates. Appl. Catal. A Gen. 2012, 443-444, 214-220. [CrossRef]

10. Seo, D.-W.; Rahma, S.T.; Reddy, B.M.; Park, S.-E. Carbon dioxide assisted toluene side-chain alkylation with methanol over Cs-X zeolite catalyst. J. $\mathrm{CO}_{2}$ Util. 2018, 26, 254-261. [CrossRef]

11. Tanabe, K.; Takahashi, O.; Hattori, H. Anomalous effect of nitrogen on side-chain alkylation of toluene with methanol over solid bases. React. Kinet. Catal. Lett. 1977, 7, 347-352. [CrossRef]

12. Yamaguchi, N.; Kobayashi, A.; Sodesawa, T.; Nozaki, F. Side-chain alkylation of toluene with methanol over Cs2O-activated carbon catalyst. React. Kinet. Catal. Lett. 1984, 25, 11-15. [CrossRef]

13. Jiang, N.; Jin, H.; Jeong, E.-Y.; Park, S.-E. MgO Encapsulated Mesoporous Zeolite for the Side Chain Alkylation of Toluene with Methanol. J. Nanosci. Nanotechnol. 2010, 10, 227-232. [CrossRef]

14. Manivannan, R.; Pandurangan, A. Formation of ethyl benzene and styrene by side chain methylation of toluene over calcined LDHs. Appl. Clay Sci. 2009, 44, 137-143. [CrossRef]

15. Li, P.; Han, Q.; Zhang, X.; Yuan, Y.; Zhang, Y.; Guo, H.; Xu, L.; Xu, L. A new insight into the reaction behaviors of side-chain alkylation of toluene with methanol over CsX. Catal. Sci. Technol. 2018, 8, 3346-3356. [CrossRef]

16. Lee, H.; Lee, S.; Ryoo, R.; Choi, M. Revisiting side-chain alkylation of toluene to styrene: Critical role of microporous structures in catalysts. J. Catal. 2019, 373, 25-36. [CrossRef]

17. Han, Q.; Li, P.; Zhang, Y.; Lu, P.; Xu, L.; Guo, H.; Xu, L. Conversion of MeOH and Toluene into Styrene and Ethylbenzene Using Composite Catalysts Containing MeOH Dehydrogenation Components. ChemCatChem 2019, 11, 1610-1614. [CrossRef]

18. Li, P.; Han, Q.; Zhang, X.; Yuan, Y.; Zhang, Y.; Xu, L.; Guo, H.; Xu, L. Explaining the influence of the introduced base sites into alkali oxide modified CsX towards side-chain alkylation of toluene with methanol. RSC Adv. 2019, 9, 13234-13242. [CrossRef]

19. Zhang, Z.H.; Shan, W.L.; Li, H.; Zhu, W.C.; Zhang, N.; Tang, Y.; Yu, J.H.; Jia, M.J.; Zhang, W.X.; Zhang, C.L. Side-chain alkylation of toluene with methanol over boron phosphate modified cesium ion-exchanged zeolite X catalysts. J. Porous Mater. 2015, 22, 1179-1186. [CrossRef]

20. Romero, M.D.; Ovejero, G.; Uguina, M.A.; Rodrı́'guez, A.; Gómez, J.M. Fast tailoring of the acid-base properties in the $\mathrm{NaX}$ zeolite by cesium-exchange under microwave heating. Microporous Mesoporous Mater. 2007, 98, 317-322. [CrossRef]

21. David, K.; Narendra, K.; Tapani, V.L.I.; Hannu, K.; Iva, K.; Heidi, O.; Dmitry Yu, M. Metal-support interactions in zeolite-supported noble metals: Influence of metal crystallites on the support acidity. J. Phys. Chem. B 2006, 110, 4937-4946.

22. Barthomeuf, D. Basic Zeolites: Characterization and Uses in Adsorption and Catalysis. Catal. Rev. 1996, 38, 521-612. [CrossRef]

23. Song, L.; Yu, Y.; Li, Z.; Guo, S.; Zhao, L.; Li, W. Side-Chain Alkylation of Toluene with Methanol over Zn-Modified KX Zeolite. J. Braz. Chem. Soc. 2014, 25, 1346-1354. [CrossRef]

24. Itoh, H.; Miyamoto, A.; Murakami, Y. Mechanism of the side-chain alkylation of toluene with methanol. J. Catal. 1980, 64, 284-294. [CrossRef] 
25. Borgna, A.; Sepulveda, J.; Magni, S.I.; Apesteguia, C.R. Active sites in the alkylation of toluene with methanol: A study by selective acid-base poisoning. Appl. Catal. A Gen. 2004, 276, 207-215. [CrossRef]

26. Serra, J.M.; Corma, A.; Farrusseng, D.; Baumes, L.; Mirodatos, C.; Flego, C.; Perego, C. Styrene from toluene by combinatorial catalysis. Catal. Today 2003, 81, 425-436. [CrossRef]

27. Unland, M.L. Infrared study of methanol decomposition on alkali metal X-type zeolites. J. Phys. Chem. 1978, 82, 580-583. [CrossRef]

28. King, S.T.; Garces, J.M. In situ infrared study of alkylation of toluene with methanol on alkali cation-exchanged zeolites. J. Catal. 1987, 104, 59-70. [CrossRef]

29. Borowiak, M.A.; Jamróz, M.H.; Larsson, R. Catalytic decomposition of formic acid on oxide catalysts-An impulse-oscillation model approach to the unimolecular mechanism. J. Mol. Catal. A Chem. 1999, 139, 97-104. [CrossRef]

30. Hunger, M.; Schenk, U.; Weitkamp, J. Mechanistic studies of the side-chain alkylation of toluene with methanol on basic zeolites Y by multi-nuclear NMR spectroscopy. J. Mol. Catal. A Chem. 1998, 134, 97-109. [CrossRef]

31. Mielczarski, E.; Davis, M.E. Infrared investigations of the alkylation of toluene with methanol by alkali-modified zeolites. Ind. Eng. Chem. Res. 1990, 29, 1579-1582. [CrossRef]

32. Dzwigaj, S.; Mallmann, A.D.; Barthomeuf, D. Adsorption of benzene and ethylbenzene on the acidic and basic sites of beta zeolite. J. Chem. Soc. Faraday Trans. 1990, 86, 431-435. [CrossRef]

33. Serra, R.M.; Miró, E.E.; Boix, A.V. FTIR study of toluene adsorption on Cs-exchanged mordenites. Microporous Mesoporous Mater. 2010, 127, 182-189. [CrossRef]

34. Aristizabal, B.H.; Montes de Correa, C.; Serykh, A.I.; Hetrick, C.E.; Amiridis, M.D. In situ FTIR study of the adsorption and reaction of ortho-dichlorobenzene on Pd-Co sulfated zirconia catalysts. J. Catal. 2008, 258, 95-102. [CrossRef]

35. Palomares, A.E.; Eder-Mirth, G.; Rep, M.; Lercher, J.A. Alkylation of Toluene over Basic Catalysts-Key Requirements for Side Chain Alkylation. J. Catal. 1998, 180, 56-65. [CrossRef]

36. Liu, H.C.; Spohn, R.J. Modified Zeolite Catalyst Composition for Alkylating Toluene with Methanol to Form Styrene. U.S. Patent 4483936, 20 November 1984.

37. Phatanasri, S.; Praserthdam, P.; Punsupsawat, T. Influence of Fe or Zn loading method on toluene methylation over MFI-type zeolite catalysts. Korean J. Chem. Eng. 2000, 17, 414-419. [CrossRef]

38. Glisenti, A.; Granozzi, G.; Favero, G. Reactivity of simple alcohols on Fe2O3powders An XPS and FTIR study. J. Chem. Soc. Faraday Trans. 1998, 94, 173-182. [CrossRef]

39. Hattori, H.; Amusa, A.A.; Jermy, R.B.; Aitani, A.M.; Al-Khattaf, S.S. Zinc oxide as efficient additive to cesium ion-exchanged zeolite X catalyst for side-chain alkylation of toluene with methanol. J. Mol. Catal. A Chem. 2016, 424, 98-105. [CrossRef]

40. Hattori, H.; Alabi, W.O.; Jermy, B.R.; Aitani, A.M.; Al-Khattaf, S.S. Pathway to Ethylbenzene Formation in Side-Chain Alkylation of Toluene with Methanol Over Cesium Ion-Exchanged Zeolite X. Catal. Lett. 2013, 143, 1025-1029. [CrossRef]

(C) 2019 by the authors. Licensee MDPI, Basel, Switzerland. This article is an open access article distributed under the terms and conditions of the Creative Commons Attribution (CC BY) license (http://creativecommons.org/licenses/by/4.0/). 